\title{
A Research on Logistics Business
}

\author{
K.Viswanathan, S.Poongavanam
}

\begin{abstract}
In the competitive universal market, the burden on establishments to select a innovative means to generate a value to the customer and supply it to them develops tougher and tougher. The growing necessity for all the companies to participate with each other in respect of their products in a international market, with regard to their cost, quality and services offered, has increased the need to develop a effective logistic systems which is more efficient than others. Consequently, in the previous two years, logistics has occupied a marvelous moved from an operating function to the business function level. There has been a rising appreciation that current logistics administration during the firm and supply chain can significantly assist in the area of price saving and facility enhancement.
\end{abstract}

Key Words: Low cost, Government initiatives, Workforce \& Research

\section{I.INTRODUCTION}

The Global Logistics Report 2007 has graded India 39 amongst 150 nations in terms of logistics attainment with its full latent. India wants combined groundwork and logistics strategy to possess the growing GDP. The main trading countries for Indian goods are US, the UAE, China, Singapore and Great Britain. The main import trading associates are China, US, Switzerland, the UAE and Belgium. BRIC nations have established energetic companies in the domain economy as the consequence of great development charges. The Indian logistics and transport engineering has gigantic budding progress predictions for native and overseas operators. Logistics industry in India is estimated to touch a market size of above $\$ 125$ billion in 2010. Outsourced logistics is slated to mature at a compound yearly progress rate of over $16 \%$ from 2007 to 2010 . The most significant supply chain issues in pharma business are inventory fall and reduction of order cycle time. It is due to working performance it may be straightly touch with the logistics costs, but stock reduction and the demand of order cycle time are linked with just-intime deliveries and supply chain speed. Shipping is an energy-efficient, environment-friendly and economical mode of transport in the Indian transport system and a critical constituent for the growth of internal business and profession. India, with her 7,517 km extended coastline dotted with 13 major ports and 200 non-major ports offers friendly and favorable situations for the expansion of this different style of transportation (R.Srinivasan, 2017). Construction product transportation is a physical activity involved in the flow of things between the point of origin and the point of consumption in order to meet requirements of customers or corporations. (R.Srinivasan\&Divyaranjini, 2018)

Pharma products necessitate boundless treatment through storage and shipping there is considerable request for temperature-controlled transport. Major LSPs have modified their services to meet the requirements, there is still a lacking of time-bound and temperature-sensitive services from the point of source to the topic of consumption. This remains a huge opportunity as far as business is concerned but high set up costs continue to be a deterrent for most logistic companies.

\section{CONSEQUENCES}

Capable staff

Economical biochemical combination

Lawful and Monetary Background

Information and Technology

Global market

\section{MAIN PHARMA PUBLIC SECTOR UNDERTAKINGS}

- Indian Drugs \& Pharmaceuticals Limited (IDPL)

- Hindustan Antibiotics Limited (HAL)

- Bengal Chemicals \& Pharmaceuticals Limited (BCPL)

- $\quad$ Rajasthan Drugs and Pharmaceuticals Ltd. (RDPL)

- Karnataka Antibiotics \& Pharmaceuticals Ltd. (KAPL)

\section{PHARMA BUSINESSES IN INDIA:}

- $\quad$ Aurobindo Pharma Ltd

- Aventis Pharma Ltd

- Cadila Pharmaceuticals Ltd

- Cipla Ltd

- Dabur Pharma Ltd

- Dey's Medical Stores Mfg. Ltd

- Dr. Reddy's Laboratories Ltd

- $\quad$ Elder Pharmaceuticals Ltd

\section{EXPORTS \& RESULTS}

DGCIS, Kolkata Exports of Drugs for the dated 20022003 to 2010-2011 are shown

Revised Manuscript Received on July 18, 2019.

K.Viswanathan, Research Scholar, AMET Business School, AMET University, Chennai, Tamil Nadu, India.

Dr. S.Poongavanam, Associate Professor, AMET Business School, AMET University, Chennai, Tamil Nadu, India. 


\begin{tabular}{|l|l|}
\hline Year & Growth $(\%)$ \\
\hline $2002-2003$ & NIL \\
\hline $2003-2004$ & 18.61 \\
\hline $2004-2005$ & 13.25 \\
\hline $2005-2006$ & 23.23 \\
\hline $2006-2007$ & 20.89 \\
\hline $2007-2008$ & 14.37 \\
\hline $2008-2009$ & 35.66 \\
\hline $2009-2010$ & 6.62 \\
\hline $2010-2011$ & 12.00 \\
\hline
\end{tabular}

\section{KEY AREAS}

- Small price technical group on works level chief to extraordinary excellence documents.

- Established greatest of achievement in strategy of great tech industrial services.

- Outstanding controlling obedience competences for functioning these possessions.

- $\quad$ New achievement record in circumventing API.

- $\quad$ Around 95 per cent of the national obligation being met through domestic production.

- India is observed as a high-grade and skillful creator in the domain.

- $\quad$ Convention investigation, Bio-technology scientific tribunals and Medical records organization.

- The nation has the division of provided that superiority healthcare at reasonable values.

\section{RESEARCH}

In manufacturing section, advanced $R \& D$ is as dangerous in Pharma manufacturing company. The New Drug Discovery Research has to possess pace with the emergent design of infections as well as replies in handling present sicknesses wherever objective organisms are charming strong to present medications. The NDDR is also an luxurious action. It is hopeful to see that at least 10 Indian corporations are into first-hand medicine detection in the areas of pollutions, metabolic conditions like diabetes, soreness, respiratory, obesity \& cancer. Most of these businesses have greater than beforehand their R\&D outlay to over 5 per cent of their separate sales turnovers.

\section{GOVERNMENT}

100 per cent FDI is allowable under the automatic route in the medicines and pharma division containing those involving use of recombinant knowledge.

\section{INVESTMENT:}

- The healthcare division has appealed rising stakeholder backing in 2010 with closely a tenth of the total private parity backing working to this division. In the third quarter the 2010, a over-all total US\$2,047 million was capitalized across 88 deals, of which 9 per cent were healthcare contracts.
- The pharma, healthcare and biotech segment observed five blend and acquisition dealings (M\&A) value US $\$ 250$ million.

- The drugs and pharmaceuticals segment has involved FDI worth US\$ 1,825.43 million between April 2000 and September 2010.

\section{CONCLUSION}

The Indian pharma divisions growing at a CAGR of 15.3 per cent during 2010-2014. The logistics compulsory for the growth and growth of the pharma region is turn out to be predictable. It productions a main part in not only to the pharma segments but also to the other areas that vital for more logistics and warehousing.

\section{REFERENCES}

1. Aldin, (2003), "Electronic commerce, marketing channels and logistics platforms - wholesalers perspective", European Journal of Operational Research, Vol. 144, pp. 270-9.

2. Chiu,(1995), "The integrated logistics management system: a framework and case study", International Journal of Physical Distribution \& Logistics Management, Vol. 25 No. 6, pp. 4-22.

3. Korpela, J. (1999), "A customer oriented approach to warehouse network evaluation and design", International Journal of Production Research, Vol. 59, pp. 135-46.

4. Lieb, R.C., (1993), "Third-party logistics services: a comparison of experienced American and European manufacturers", International Journal of Physical Distribution \& Logistics Management, Vol. 23 No. 6, pp. 35-4

5. Rao, B. (1999), "The Internet and the revolution in distribution: a cross-industry examination", Technology in Society, Vol. 21, pp. 287-306.

6. Srinivasan, R., Poongavanam, S., (2017) A study on coastal container services operation in India, International Journal of Mechanical Engineering and Technology, 8 (11), pp.1103-1110.

7. Srinivasan, R., Poongavanam, S., Divyaranjini, R.(2017). Construction product movement in NTC - A case study analysis, International Journal of civil Engineering and Technology, 9 (9), pp.942- 946. 